\title{
Is "law as a social system" bad for women? A preliminary analysis of the Luhmannian approach to law from a feminist perspective
}

\author{
Mariana Assis*
}

\begin{abstract}
Women's struggle for emancipation can be characterized, among other elements, as an ongoing process for, first, entering the legal system and second, attempting to change it. This, nonetheless, stirs up conflicts and certain perplexities, as appropriately summarized by Al ejandra Ciriza under the label the Wollstonecraft dilemma: the politicization of sexual difference, which constitutes the center of feminist struggle in modernity, faces a twofold obstacle. On the one hand, the presentation of sexual difference in the public sphere leads to the transformation of any question related to it into a vindication of rights. On the other hand, the judicialization and institutionalization of such demands lead to the recognition of the limits and impossibilities of a politics of rights (Ciriza, 2004, p. 210). Given the fact that there is this uncontestable and paradoxical relationship between women's political struggle for equality and the legal system, this paper aims to evaluate a specific approach to law, that is, Luhmann's account of law as a social system from a feminist perspective. The question guiding the discussion proposed here is the following: is the theory of law as a social system able to incorporate feminist contentions to law? In order to do so, the Luhmaniann theoretical framework and its most important concepts is presented and discussed. Then, this framework is reviewed through a feminist perspective, particularly by the confrontation with a feminist agenda of law that is based primarily on feminist legal theory and theories of patriarchy. At the end, I hope to accomplish the twofold intention of this paper: first, to point the limits of Luhmann's approach to law from a feminist standpoint and, second, to show the relevance of gender analysis in the legal field.

Keywords: feminism, sexual difference; gender and law; Luhmann.
\end{abstract}

\section{Introduction: the relationship between law and women's struggle for equality}

In modernity, women's struggle for equity and emancipation has always had a strong and conflicting relationship with law. During the American Revolution, more precisely in the year of the Second Continental Congress (1776), Abigail Adams wrote a letter to her husband, John Adams, that would later became famous, in which she asks the lawmakers of the Congress to "remember the ladies" in the new Code of Laws,

\footnotetext{
* Ph.D. student at the Department of Politics at the New School for Social Research. Email: marianaprandini@gmail.com.
} 
otherwise, they were "determined to foment a Rebellion", for they would not obey any law in which they have no voice or representation (Rossi, 1988, p. 10-11).

Some years later, during the French Revolution, there was another example of women claiming their rights. The document called Declaration of the Rights of Woman and Female Citizen was proposed for the Constitutional French Assembly, in 1791, by Marie Gouze, who at that time adopted the name Olympe de Gouges to sign her petitions and papers used as political ads. Despite the extremely transformative character of that moment in France, the revolutionaries were not capable of going far enough to recognize women as citizens. Olympe was beheaded in 1793 being condemned as a counter revolutionary and stigmatized as a subversive woman.

Interestingly enough, at the same time yet in another place, given the influence of "the climate of political commotion generated by the French Revolution" (Ciriza, 2004, p. 207), another woman vindicated the right to participate in the political order. In 1792, in London, Mary Wollstonecraft published $A$ vindication of the rights of woman. Positioning herself against Rousseau, Wollstonecraft harshly criticized the patriarchal society and assumed a perspective of difference considering women's position in society. Alejandra Ciriza (2004) argues that Wollstonecraft demonstrated how women's place in society - characterized by subordination and denied access to social goods and spaces - was a direct result of how corporal differences were transformed into complementary and hierarchically structured gender roles.

In Brazil, some years later, precisely in 1833, in Recife, Nísia Floresta published her first book. It was, as Constância Lima Duarte has shown (1997), "also the first one in Brazil that dealt with women's right to education and work". In addition, it "demanded women to be considered as intelligent beings and worthy of society's respect" (Duarte, 1997). The referred book, The rights of women and the injustice of men, was inspired by Wollstonecraft, Poulain de La Barre, Sophie and Olympe de Gouges' works (Duarte, 1997) and played a very important role in Brazilian feminist history. From this great beginning, there were many others audacious appearances of Brazilian women who, individually or collectively, turned the feminist struggle into a struggle for rights. 
These simple and varied historical references are able to demonstrate that across the world, women's struggle for emancipation can be characterized, among other elements, as an ongoing process for, firstly, an entrance into the legal system and secondly, attempts to change it. This, nonetheless, stirs up conflicts and certain perplexities, as appropriately summarized by Alejandra Ciriza under the label "the Wollstonecraft dilemma": the politicization of sexual difference, which constitutes the center of feminist struggle in modernity, faces a twofold obstacle. On the one hand, the presentation of sexual difference in the public sphere leads to the transformation of any question related to it into a vindication of rights. On the other hand, the judicialization and institutionalization of such demands lead to a clear consciousness of the limits and impossibilities of a 'politics of rights' (Ciriza, 2004, p. 210).

Given the fact that there is this uncontestable and paradoxical relationship between women's political struggle for equality and the legal system, this paper aims to evaluate a specific approach to law, that is, Luhmann's account of "law as a social system" from a feminist perspective. The question that will guide the discussion proposed here is the following: is the theory of law as a social system able to incorporate feminist contentions to law? In order to do so, the Luhmaniann theoretical framework and its most important concepts will be presented and discussed. Then, the framework will be reviewed through a feminist perspective, particularly by the confrontation with a feminist agenda of law that is based primarily on feminist legal theory studies and theories of patriarchy. At the end, I hope to be able to accomplish the twofold intention of this paper: firstly, to point the limits of Luhmann's approach to law from a feminist standpoint and, secondly, to show the relevance of gender analysis into the legal field.

Before turning to Luhmann's theory, let me clarify what I mean by a feminist perspective. First, it is necessary to recognize that many different approaches fall under the label feminist theory and they are framed upon different concepts, notions and hypotheses. Nevertheless, "they generally share certain basic commitments. At the substantive level, feminism presupposes a commitment to equality between the sexes. At the methodological level, it implies a commitment to gender as a focus of 
analysis and to approaches that reflect women's perspectives and concerns" (Rhode, 1994, p. 1182). It is from this standpoint that this paper departures.

\section{Law as a social system: an overview of Luhmann's theory of society and law}

Luhmann $(2008,1988)$ builds his theory of society and law using concepts from the evolutionary theory, but combines them with other ones that come from the theory of difference. His attempt is to make the concept of evolution more precise, for it had already been used in the legal field, but, by his account, without any accuracy. In order to do so, he borrows the concept of evolution from Darwin's theory and makes it clear that evolution is not a synonym of progress. On the contrary, it is a complex process of both differentiation and adaptation, which occurs in the relationship between system and environment. It is inevitable, in the sense that it cannot be stopped, and it is also improbable, in the sense that it is not possible to guide evolution beforehand, in the direction one wants.

Thus, Luhmann describes the evolution of modern societies as a functional differentiation process, through which societal structuring elements that once were undifferentiated detach one from the other and form autopoietic specialized systems. Society is thus described as a complex social system, whose different functions are carried out by differentiated sub-systems. In sum, for Luhmann, social evolution is conceived as a differentiation process of social sub-systems with specific functions.

Given that, Luhmann turns to the question of which characteristics of a system make evolution possible. And he answers that it would be "the pressure of selection that arises from the operative closure of systems and their limited complexity in relation to the world" (Luhmann, 2008, p. 232). He is working with the concept of an autopoietic system, which means a system that is self-reproductive or, in other terms, a system that establishes its own forms of production and that does not depend on external elements to reproduce itself. Then, the systems he is describing evolve because the world becomes more complex along time and requires from them new and different responses, which they give in their own terms. It is also important to 
clarify that, in Luhmann's account, each system operates under a binary code and everything that enters the system must be translated in terms of its guiding code.

For Luhmann, law is such a kind of system, or better said, a social sub-system, whereas society is a social system where one can find functionally differentiated subsystems. It has the function of processing "normative expectations that are capable of maintaining themselves in situations of conflict" (Luhmann, 1988, p. 140), providing thus cohesion to social life through the reduction of complexity of the alternatives of actions. Law accomplishes this task by protecting expectations for it contains preliminary decisions for the conflicts that can emerge within society. In order to protect these expectations, the legal system developed a binary code: legal $x$ illegal. In this sense, everything that gets inside the legal system will be labeled according to this code "and anything that does not fit into this code is of legal significance only if it is important as a preliminary question in decisions about justice and injustice" (Luhmann, 1988, p. 140).

According to Luhmann, this coding has two important functions: firstly, it permits the legal system to perform its function within society, through the codification of each disappointed expectation that enters it; secondly, it "serves the autopoietic reproduction of the system", in the sense that "it makes it possible to examine all processing of normative expectations in terms of the key question whether or not the processing is compatible with previous processing" (Luhmann, 1988, 140). Through this mechanism, law not only regulates its own regulation, but also determines its own modification. Furthermore, it establishes its own mechanism of evaluation. (Luhmann, 1988, p. 141).

The legal system has, thus, "a self-referential, closed character" (Luhmann, 1988, p. 141) and for that its boundaries are defined "at the operative level", "by the legal system itself" (Luhmann, 1988, p. 141). In this sense, "every communication that makes a legal assertion or raises a defense against such an assertion is an internal operation of the legal system" (Luhmann, 1988, p. 141), and for that has to follow the binary coding lawful/unlawful.

However, a long process of evolution unfolded until the legal system finally gained the autopoietic character given to it by Luhmann. In addition, this was an 
independent evolution, because the thesis of an independent autopoiesis of the legal system leads to the affirmation of an independent evolution of the legal system. Luhmann describes this evolution in three different stages - archaic law, law of the ancient cultures and positive law (Luhmann, 1983) - and calls attention to varied innovations which occurred throughout the course of history.

One of the evolutionary changes deeply discussed by Luhmann is the existence of written records or the invention of writing and its impact within the legal system. The author describes how writing influenced changes in the legal system, the different usages of writing inside it, the relevance of writing for the validity of law - as a condition of validity itself - and how writing contributed to the development of a particular specialized group responsible for interpreting it.

Another decisive deviation for the evolution of the legal system pointed by Luhmann "[...] occurred when in the proceedings [...] arguments were no longer made exclusively ad hoc and ad hominem" ((Luhmann, 2008, p. 248). Law gained autonomy from the social structures outside the legal system, especially class-related status and familial relationships, friendships, and patronage; and then differentiated itself from morals, common sense, and everyday use of words. When these arguments that come from sources placed outside the law are no longer permitted as valid ones, a demand for justification arises and it contributes to the emergence of a concept of justice in the following terms: equal cases must be treated equally and different cases, unequally. Another development that can be seen as a sort of result of this change is the differentiation of special roles for legal experts, for lawyers.

Another point stressed by Luhmann is the relevance of legal dogmatics to the stabilization and restabilization of law, because it "guarantees that the legal system approves itself in its change as a system" (Luhmann, 2008, p. 257). Legislation is also considered a "sort of innovation for the fixing of defects" (Luhmann, 2008, p. 258); with it, law has its own mechanism to change itself, without being necessary to count on external sources. The consequence of this evolution is that there is only positive law: law which the legal system itself implements with the symbol of legal validity. Moreover, the concept of subjective rights was also an important achievement of the 
evolution of law, especially the idea of universal subjective rights, which destroyed the basis of stratified society and the very notion of rights linked to social status.

Finally, Luhmann points out the role interpretation plays in the evolutionary process of law, as it "performs a consistency test by examining which meaning of a norm fits in the context of other norms" (Luhmann, 2008, p. 260). This is in fact the last step of the evolutionary path of law, for from this development on law can be changed through interpretation, without necessarily having to change its text. At this point then, law can be characterized as a completely differentiated and autopoietic social system which has the specific function of stabilizing expectations by pre-establishing solutions to possible conflicts.

Besides being autopoietic and autonomous, law is also operatively closed, which means that the legal system specifies its own structures by its operations and change them if events, internally identified, so demand. Nevertheless, this operative closure does not mean that the legal system does not interact with other systems. Examining these interactions, Luhmann pays close attention to two other social systems: politics and economy.

Though dependent of each other, law, politics and economy are different subsystems of society, each guided by their own code. They can be considered different sub-systems of society due to their autopoieses: each of them defines "the elements that are allowed to operate within a network of operations, by the network of its own operations" (Luhmann, 2008, p. 378). Even though, as already noticed, the differentiation of the systems does not mean that there are no relations between them. On the contrary, there are many relations - as already pointed out - and each system has been able to develop by conditioning and stimulating each other. This is possible because of both the separation of systems and the existence of a mechanism of their structural coupling.

The legal system is coupled with the political and the economic systems, respectively, by the constitution, the property and the contract. These forms of structural coupling "reduce and so facilitate influences of the environment on the system" (Luhmann, 2008, p. 382). 
It is important to notice that Luhmann rejects natural law theories, which means that he opposes those theories that assume there are universally valid rules for the whole society. Seeing law as a social system means to characterize law as a dependent variable of the society (just as the society is also a dependent variable of law). In other words, law evolves in relation to the development and changes of society and the rules are created as a demand from the society in order to solve social problems. But it also signifies that the changes that have occurred within the legal system impact the evolution of the society. Nevertheless, "it does not mean that the environment [that is, society] determines the legal system. Rather, the legal system notices defects only in its own devices and fixes them with its own means" (Luhmann, 2008 , p. 258). In a very basic sense, law is autopoietic and always contingent. What society does is only give accidental impulses, which causes variations and innovative selections.

In summary, law is a subsystem of society, among other subsystems such as politics, economy, religion, education, and so on, that is to say, "the legal system is a differentiated functional system within society" (Luhmann, 1988, p. 138) and, thus, can not be equated to the other mentioned sub-systems. This assumption leads to the conclusion that when law is reproducing itself - a process named as autopoiesis - it is actually also reproducing the entire social system. To perform this ability, law resorts to forms of communication that can be understood outside its own sphere. The existing connection between law and society is thus twofold: firstly, the legal system has a specific role in the social system, that is, it performs a differentiated function for society, and, secondly, "the legal system participates in society's construction of reality" (Luhmann, 1988, p. 138).

Law is both dependent and independent from society. This means, in the theory of social system, that law depends on its environment - that is, society - to grow, but, at the same time, it is autonomous when its own operations are concerned, which means that the legal system decides for itself what is legal and what is illegal and, to do that, it must appeal to its own operations.

According to Luhmann (1988, p. 138), accessing the social character of law requires the acceptance of two conceptual innovations: (1) the notion of 
differentiation, which establishes that the systems differentiate themselves from the environment and establish relationships with it; (2) this differentiation between systems and environment and their respective operations is only possible because the first establish a closure that is self-referential, which means that it sets its own terms of production and reproduction.

Finally, with his idea of "a full differentiation of the legal system [that] leads to the universalization of its code" (Luhmann, 2008, p. 273), Luhmann builds the notion that there are no limitations outside the legal system of what is going to be integrated in it: limitation is only self-limitation, which is to say, it is the legal system itself which establishes what is going to be subject to law and what is not going to be so.

\section{Is the concept of law as a social system open to feminist contentions?}

As demonstrated in the previous section, "Luhmann's perspective contends that the production and evolution of law cannot be attributed to extra-legal influences" (Deflem, 1998, p. 786), due to the fact that it is a closed self-referentiated system. Furthermore, there is an important hypothesis backing Luhmann's theory: that the transition from traditional to modern society was a transition from a stratified differentiated social system to a functionally differentiated social system, which means, the traditional society was organized through familial and tribal ties, while, in modern society, the organization occurs through the differentiation of sub-systems, each of them tied to a particular function and structured upon a specific binary code (Cornell, 1991, p. 793).

From a feminist perspective, the assumptions stated above are at the very least problematic, because they completely disregard the fact that there is still a patriarchal system which operates in different social spheres, maintaining or even deepening women's subordination. Moreover, the structural elements of this patriarchal system can be identified in different sub-systems described by Luhmann and are all of them, to varying degrees, connected to the legal system, via some kind of regulation or even non-regulation. Let me clarify this point in a more detailed manner. 
Sylvia Walby defines patriarchy "as a system of social structures and practices in which men dominate, oppress and exploit women" (Walby, 1990, p. 20). By using the term social structure she wants to both banish any possibility of patriarchy being read in a biological determinist perspective and to establish that neither is every man nor is every woman, respectively, in the position of oppressor and oppressed. Still according to Walby, patriarchy can be assessed from two different levels, one more abstract and another less abstract. At the first level, "it exists as a system of social relations"; at the second one, "it is composed of six structures: the patriarchal mode of production, patriarchal relations of paid work, patriarchal relations in the state, male violence, patriarchal relations in sexuality, and patriarchal relations in cultural institutions" (Walby, 1990, p. 20). The identification of these six different bases of patriarchy is important because it guarantees the necessary analytical instrument to assess a reality that is increasingly complex and thus avoids reductionism and essentialism. Although analytically distinct and relatively autonomous at the operative level, these elements "have effects upon each other, both reinforcing and blocking" (Walby, 1990, p. 20). They also vary in time and space and must be analyzed in a deep way according to different contexts. In order to address the question posed at the beginning of this paper, I will relate each of these elements of the patriarchy system to the legal system, aiming to show the problems that emerge from treating the latter as self-referentiated and thus not impacted by the first.

The patriarchal production relations in the household can be defined as the way through which "women's household labour is expropriated by their husbands or cohabitees" (Walby, 1990, p. 21). As many research reports have demonstrated (such as Hausmann, Tyson, and Zahidi, 2009), women are, even when they dedicate themselves to some type of paid job, the ones responsible for the major part of the housework and caretaking. How does this then relate to the legal system, since household labor happens inside the private sphere and does not seem not to be an issue for legal regulation? Amidst many other instances, there is a strong vindication from women's and feminist movements for the recognition of unpaid household labor, by the social security and retirement systems, on the issue of assuring stipends. This vindication is based on the fact that women dedicate an overwhelming part of their 
lives to these activities, which are, nevertheless, invisible. In the US, for example, according to the analysis of the Time Use Survey provided by Rachel Krantz-Kent (2009, p. 48), during the years 2003 to 2007, "women spent an average of 6.3 hours more per week doing household activities than did men (15.5 versus 9.2 hours) and 2.4 hours more per week providing care to household members (4.4 versus 2.0 hours)". In Luhmann's account, it would be read just as an irritation which the legal system did not make the choice to convert into legal terms of lawful/unlawful. This perspective, certainly, only serves to cover how the patriarchal system helps to maintain the sexual division of labor and to legitimate the lesser value attributed to women's activities.

The second element, patriarchal relations within paid work, is explained by Walby (1990, p. 21) as those mechanisms which "exclude women from the better forms of work and segregate them into the worse jobs which are deemed to be less skilled". The relationship between this element of the patriarchal system and law seems to be clear. On the one hand, many countries, for they have recognized the impact of gender within the labor market, which means that they explicitly corroborated Walby's assertion of an existence of patriarchal relation in the work place, passed affirmative action laws in order to guarantee equal opportunities for women in this sphere. These laws are not gender blind and explicitly address issues that are outside the legal system and do not obey the code lawful/unlawful, that is to say, the mechanisms outside the legal system which prevent women from getting the better job positions. On the other hand, as Joanne Conaghan has already demonstrated, "labour law is a world made up of full-time male bread-winners and the legal rules reflect this conception of the worker" (Conaghan, 1995, p. 345). With this statement, she aims exactly to show that when labor law claims a gender neutral approach - which seems to be the Luhmannian perspective - it actually embraces a male standpoint, for it does not admit that sexual differences play an important role in the labor place. In this sense, there is a tense relationship between labor law and patriarchy: some advances from a feminist perspective can be pointed out in this branch of law, but they occurred only in those circumstances that the patriarchal conceptions which dominate this legal field, as asserted by Conaghan, were explicitly recognized and addressed. 
The third structuring element of the patriarchy system pointed by Walby (1990, p. 21) is the state, which "has a systematic bias towards patriarchal interests in its policies and actions". The connection of this element and law seems to be explicit: for Luhmann, law is positive law, which means, law is that body of norms produced by the state according to a previously established procedure. If this is so and if the state has a patriarchal bias when planning and executing its policies and actions, the legal system will, to a lesser or greater extent, embody this same bias, in the way feminist legal scholarship has demonstrated (Mackinnon, 1983). One example usually pointed by feminist theorists are the welfare policies, which stigmatize women as recipients of state's help and do not provide them with the necessary means to overcoming their disadvantaged position.

Male violence, the fourth element, "constitutes a further structure, despite its apparently individualistic and diverse form. It is behaviour routinely experienced by women from men, with standard effects upon the actions of most women" (Walby, 1990, p. 21). In this issue, law definitively plays a very important role. It should be noted that for quite a long period of time, violence against women was not even deemed a legal concern. There was no specific regulation on this matter and, for this reason, many women lost their lives. After many years of feminist struggle, different countries around the world passed acts expressly directed at confronting violence against women and, just as the affirmative action acts mentioned before, they are not gender blinded. Moreover, they represent the result of a strong social movement pressuring the state in order to produce such type of norms.

The maintenance of patriarchal relations in sexuality, whose key forms are "compulsory heterosexuality and the sexual double standard are two of the key forms of this structure" (Walby, 1990, p. 21), constitutes the fifth element. Once more, the relationship between this element of the patriarchal and the legal systems seems to be very clear. In different countries of the world, there is an ongoing struggle of the LGBT (lesbian, gay, bisexual, transsexual and transgender) movement to pass laws which enfranchise same-sex couples with the right to marry. This vindication is necessary because most of the Western democracies only recognize the right to get married to different-sex couples. Why so? Is it only a question of a self-referentiated legal system 
which decided to code different-sex marriage as legal and same-sex marriage as illegal? In a gender perspective, the answer is no. This norm actually incorporates, or better said, legalizes a compulsory heterosexuality norm that guides the Western patriarchal society and that is why pressures from outside the legal system have so little acceptance.

And, finally, the sixth element is the patriarchal cultural institutions, "composed of a set of institutions which create the representation of women within a patriarchal gaze in variety of arenas, such as religions, education and the media" (Walby, 1990, p. 21). These institutions play a very important role in shaping subjectivities which are gender-differentiated or, in other words, they create some standards of what it means to be a man and what it means to be a woman and, by doing this, they help to maintain the patriarchal system as whole. The relationship between them and the law can be established in the following way: the standards created by those institutions inform the production of law - just remember the cases of labor law and violence against women - and law can function both as a tool which reinforces or challenges them.

Once demonstrated the relationships each of the different elements of the patriarchy system establish with the legal system, it is necessary to clarify that the theorists of patriarchy do not state it is an unchangeable entity. On the contrary, as claimed by Walby, "we need to separate the notion of progress in the position of women from that of changes in the form of gender inequality. [...] There have been major alterations in the form of patriarchy as well as in its degree ${ }^{1 "}$ (Walby, 1990, p. 23). It means that all those elements are subjected to transformation and that is why a substantial inquiry on women's situation within society demands a deep analysis of how each of them are actually functioning. As an example of these type of changes is the fact that wages and education gaps between men and women have decreased in almost all western democracies due to, firstly, a strong struggle of feminist and

\footnotetext{
${ }^{1}$ According to Walby (1990, p. 174), "degrees of patriarchy refers to the intensity of oppression on a specified dimension", such as education or wage. Forms of patriarchy, on the other hand, refer "to the overall type of patriarchy, as defined by the specific relations between the different patriarchal structures" (1990, p. 174). Here, Walby makes the distinction between public patriarchy, which "is based principally in public sites such as employment and the state" and private patriarchy, maintained "upon household production as the main site of women's oppression" (Walby, 1990, p. 24).
} 
women's movement and, secondly, the implementation of policies that definitely are not gender blind.

Then, what is problematic in the Luhmannian approach? Luhmann's theory explicitly "denies the relevance of extra-legal contexts conditioning the operation of law" (Deflem, 1998, p. 786) and, for this reason, pressures which come from outside the legal system are characterized only as "irritation". Once they enter the legal system, they must be translated into the binary code lawful/unlawful.

As I tried to show above, feminist contentions to law demonstrate that Luhmann's description does not correspond to the reality of the production or the application of law. If in earlier times, women could not even establish civil contracts with their own names because they were not entitled basic civil rights, today Western legal systems have changed and guaranteeing that women can take part in the life of democratic polities as citizens. Nevertheless, Pateman argues that "this change alone does not alter the patriarchal 'foundation' of the myths which justify civil society" (Cornell, 1991, p. 788). In this sense, Pateman shows how "the social contract is itself contaminated by patriarchy" and "why 'neutral' language in law will itself not be 'neutral' at all, but an expression of the gender hierarchy" (Cornell, 1991, p. 790). She demonstrates "why it is so difficult to sustain and justify legal reform under the traditional concepts of the legal system" (Cornell, 1991, p. 790), since the dismantling of traditional gender hierarchies or of patriarchy has not occurred. In Pateman's account:

\begin{abstract}
The juridical equality and legal reform so central to contract doctrine (and which, contrary to the impression cultivated on all sides, has not yet been completely achieved) is invariably seen today as a matter of women acting like men. The suffrage, and more recent reforms such as the participation of women on juries, equal-pay and anti-discrimination legislation, reform of marriage and rape law, decriminalization of prostitution, are all seen as allowing women to become citizens like men and owners of property in their persons like men (Pateman, 1988, p. 227).
\end{abstract}

For this reason, a feminist legal theory approach seems to be more adequate to address women's issues than Luhmman's perspective, at least, in the current situation experienced by Western legal systems. From an analytical standpoint, feminist legal theory firmly establishes that sex/gender is an important type of social structure which 
characterizes and influences the production, the content and the interpretation of law. From the ethical-political perspective, it states that biological differences were misused to produce a social differentiation among people and designated women to a subordinated, oppressed and despised place. In this process, law functions as an important mechanism for producing and reproducing gender inequality. And, finally, considering methodology, feminist legal theory does not assume a dogmatic attitude ${ }^{2}$ toward its object. On the contrary, it is characterized by a critical scrutiny of law and legal practices, made possible by the always present linkage between theory and practice.

Hence, academic law feminists conduct their research in a manner that is capable of showing how law is both gendered and not neutral, seeking to demonstrate the existing link between law and the condition of subaltern woman, in order to promote social change. In this theoretical field, law is seen as a byproduct of the social construction of reality. As Deborah L. Rhode argues (1989, p. 2), "law is an important social text, which illuminates as well as influences the cultural construction of gender". Consequently, it becomes an instrument that can reinforce stereotyped gender roles, 'legalizing' through its discourse, inequalities. Yet it may very well contribute to the production of a more egalitarian context. In this sense, it would function as a catalyst seeking to overcome gender dominance.

What feminist legal theory provides is exactly what is missing in the Luhmannian approach, that is, the demonstration of the undeniable relationships that exist between the legal system and the patriarchal system. Although Luhmann recognizes that impulses exist from outside the legal system, he firmly sustains that "modern law is at the level of its own operation completely autonomous and closed" (Deflem, 1998, p. 784) and, for this reason, legal changes only occur "because of changes within the legal subsystem itself" (Deflem, 1998, p. 784). This account firmly denies that pressures which come outside the legal system not only propel towards change but actually shape these changes. And the vindicated equality between men and women inside the legal system will occur only when women's equal standing is

\footnotetext{
${ }^{2}$ It is important to note here that the dogmatic perspective, characterized as accepting positive norms as a presupposition that is unquestionable in any investigation, is strongly privileged in academic studies within Brazilian Law.
} 
"accepted as an expression of the freedom of women as women, and not treated as an indication that women can be just like men" (Walby, 1990, p. 231).

\section{Referências bibliográficas}

Ciriza, Alejandra. 2004. "Passado e presente: o dilema Wollstonecraft como herança teórica e política." In Teoria e filosofia política, 207-233. Edusp/Clacso.

Conaghan, Joanne. 1995. "The Invisibility of Women in Labour Law: Gender-neutrality in Mode-building." In Feminist Legal Theory II: Positioning Feminist Theory within the Law, 345360. New York: New York University Press.

Cornell, Drucilla L. 1991. "Philosophy of the Limit, Systems Theory and Feminist Legal Reform." New England Law Review 26: 783-804.

Cornell, Drucilla L. 1996. "Enabling Paradoxes: Gender Difference and Systems Theory." New Literary History 27, no. 2: 185-197.

Deflem, Mathieu. 1998. "The Boundaries of Abortion Law: Systems Theory from Parsons to Luhmann and Habermas." Social Forces 76, no. 3 (March): 775-818.

Duarte, Constância Lima. 1997. "Nísia Floresta Brasileira Augusta: Pioneira do Feminismo Brasileiro - Séc. XIX." Mulheres $e$ Literatura 1. http://www.litcult.net/revistamulheres_vol1.php?id=7.

Hausmann, Ricardo, Laura D. Tyson, and Saadia Zahidi. 2009. The Global Gender Gap Report 2009. Geneva: World Economic Forum.

Krantz-Kent, Rachel. 2009. "Measuring time spent in unpaid household work: results from the American Time Use Survey." Monthly Labor Review 132, no. 7 (July): 46-59.

Luhmann, Niklas. 1983. Sociologia do Direito I. Tempo Brasileiro.

Luhmann, Niklas. 1988. "Law As a Social System." Northwestern University Law Review 83: 136-150.

Luhmann, Niklas. 2008. Law as a Social System. $1^{\circ}$ ed. Oxford University Press.

MacKinnon, Catharine A. 1983. "Feminism, Marxism, Method, and the State: Toward Feminist Jurisprudence." Signs 8, no. 4 (Summer): 635-658.

Pateman, Carole. 1988. The sexual contract. Stanford: Stanford University Press. 
Rhode, Deborah L. 1994. "Feminism and the State." Harvard Law Review 107, no. 6 (April): 1181-1208.

Rossi, Alice S. 1988. The Feminist Papers: From Adams to de Beauvoir. Northeastern. 